
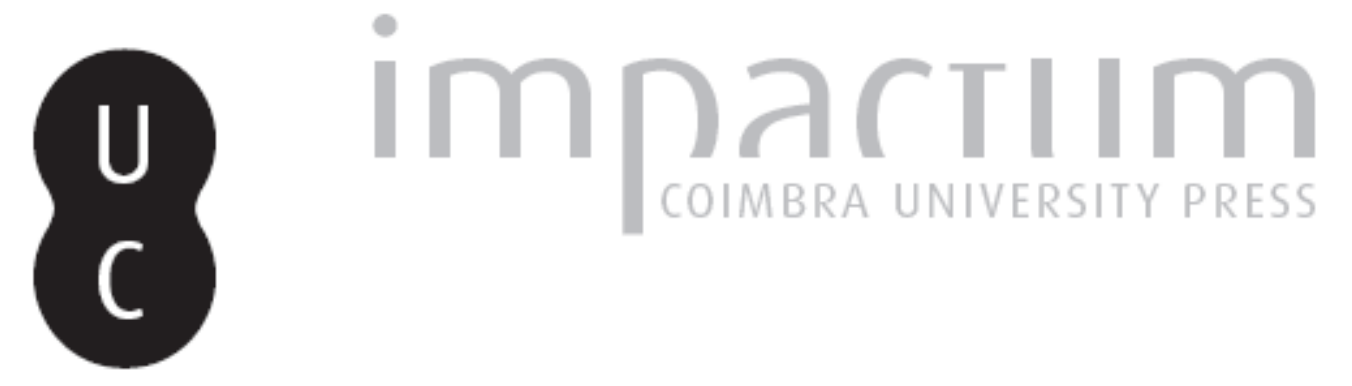

\title{
A modest proposal for resolving the eurozone crisis
}

Autor(es): $\quad$ Varoufakis, Yanis; Holland, Stuart; Galbraith, James K.

Publicado por: Imprensa da Universidade de Coimbra

URL persistente:

URI:http://hdl.handle.net/10316.2/36578

DOI:

DOI:http://dx.doi.org/10.14195/2183-203X_41_1

Accessed : $\quad$ 26-Apr-2023 10:33:53

A navegação consulta e descarregamento dos títulos inseridos nas Bibliotecas Digitais UC Digitalis, UC Pombalina e UC Impactum, pressupõem a aceitação plena e sem reservas dos Termos e Condições de Uso destas Bibliotecas Digitais, disponíveis em https://digitalis.uc.pt/pt-pt/termos.

Conforme exposto nos referidos Termos e Condições de Uso, o descarregamento de títulos de acesso restrito requer uma licença válida de autorização devendo o utilizador aceder ao(s) documento(s) a partir de um endereço de IP da instituição detentora da supramencionada licença.

Ao utilizador é apenas permitido o descarregamento para uso pessoal, pelo que o emprego do(s) título(s) descarregado(s) para outro fim, designadamente comercial, carece de autorização do respetivo autor ou editor da obra.

Na medida em que todas as obras da UC Digitalis se encontram protegidas pelo Código do Direito de Autor e Direitos Conexos e demais legislação aplicável, toda a cópia, parcial ou total, deste documento, nos casos em que é legalmente admitida, deverá conter ou fazer-se acompanhar por este aviso.

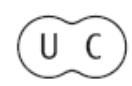




\section{N $\odot$ TASEC N}

YANIS VAROUFAKIS / STUART HOLLAND / JAMES K. GALBRAITH STUART HOLLAND MANUEL LOPES PORTO NUNO SILVA
A MODEST PROPOSAL FOR RESOLVING THE EUROZONE CRISIS

FALSE START FOR THE JUNCKER RECOVERY PROPOSALS EUROPA EM QUESTÃO: COMENTÁRIO

TIME-VARYING STOCK RETURN PREDICTABILITY:

THE EUROZONE CASE

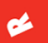

$\rightarrow$

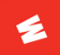

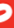

$\checkmark$

$\omega$

$\theta$

mi

-

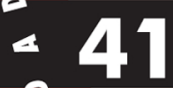
$-$

$\infty$

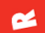
w $\Rightarrow$ $=$ $\theta$ 4

Q $\alpha$ 


\section{A Modest Proposal for Resolving the Eurozone Grisis}

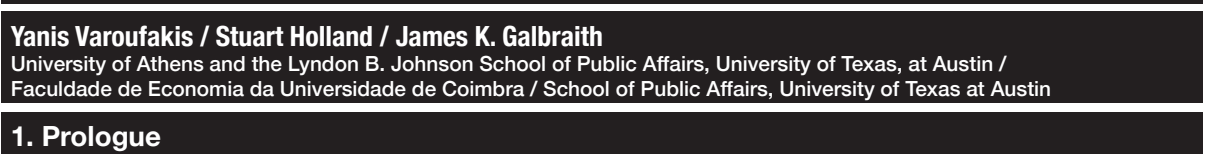

Europe is fragmenting. While in the past year the European Central Bank has managed to stabilise the bond markets, the economies of the European core and its periphery are drifting apart. As this happens, human costs mount and disintegration becomes an increasing threat.

It is not just a matter for the Eurozone. The fallout from a Eurozone breakup would destroy the European Union, except perhaps in name. And Europe's fragmentation poses a global danger.

Following a sequence of errors and avoidable delays Europe's leadership remains in denial about the nature of the crisis, and continues to pose the false choice between draconian austerity and a federal Europe.

By contrast, we propose immediate solutions, feasible within current European law and treaties.

There are in this crisis four sub-crises: a banking crisis, a public debt crisis, a crisis of underinvestment, and now a social crisis - the result of five years of policy failure. Our Modest Proposal therefore now has four elements. They deploy existing institutions and require none of the moves that many Europeans oppose, such as national guarantees or fiscal transfers. Nor do they require treaty changes, which many electorates anyway could reject. Thus we propose a European New Deal which, like its American forebear would lead to progress within months, yet through measures that fall entirely within the constitutional framework to which European governments have already agreed.

\section{The nature of the Eurozone crisis}

The Eurozone crisis is unfolding on four interrelated domains.

Banking crisis: There is a common global banking crisis, which was sparked off mainly by the catastrophe in American finance. But the Eurozone has proved uniquely unable to cope with the disaster, and this is a problem of structure and governance. The Eurozone features a central bank with no government, and national governments with no supportive central bank, arrayed against a global network of mega-banks they cannot possibly supervise. Europe's response has been to propose a full Banking Union - a bold measure in principle but one that threatens both delay and diversion from actions that are needed immediately.

Debt crisis: The credit crunch of 2008 revealed the Eurozone's principle of perfectly separable public debts to be unworkable. Forced to create a bailout fund that did not violate the no-bailout clauses of the ECB charter and Lisbon Treaty, Europe created the temporary European Financial Stability Facility (EFSF) and then the permanent European Stability Mechanism (ESM). The creation of these new institutions met the immediate funding needs of several member-states, but retained the flawed principle of separable public debts and so could not contain the crisis. One sovereign state, Cyprus, has now de facto gone bankrupt, imposing capital controls even while remaining inside the euro.

During the summer of 2012, the ECB came up with another approach: the Outright Monetary Transactions' Programme (OMT). OMT succeeded in calming the bond markets for a while. But it too fails as a solution to the crisis, because it is based on a threat against bond markets that cannot remain credible over time. And while it puts the public debt crisis on hold, it fails to reverse it; ECB bond purchases cannot restore the lending power of failed markets or the borrowing power of failing governments. 
Investment crisis: Lack of investment in Europe threatens its living standards and its international competitiveness. As Germany alone ran large surpluses after 2000, the resulting trade imbalances ensured that when crisis hit in 2008, the deficit zones would collapse. And the burden of adjustment fell exactly on the deficit zones, which could not bear it. Nor could it be offset by devaluation or new public spending, so the scene was set for disinvestment in the regions that needed investment the most.

Thus, Europe ended up with both low total investment and an even more uneven distribution of that investment between its surplus and deficit regions.

Social crisis: Three years of harsh austerity have taken their toll on Europe's peoples. From Athens to Dublin and from Lisbon to Eastern Germany, millions of Europeans have lost access to basic goods and dignity. Unemployment is rampant. Homelessness and hunger are rising. Pensions have been cut; taxes on necessities meanwhile continue to rise. For the first time in two generations, Europeans are questioning the European project, while nationalism, and even Nazi parties, are gaining strength.

\section{Political constraints for any solution}

Any solution to the crisis must respect realistic constraints on political action. This is why grand schemes should be shunned. It is why we need a modest proposal.

Four constraints facing Europe presently are:

(a) The ECB will not be allowed to monetise sovereigns directly. There will be no ECB guarantees of debt issues by member-states, no ECB purchases of government bonds in the primary market, no ECB leveraging of the EFSF-ESM to buy sovereign debt from either the primary or secondary markets.

(b) The ECB's OMT programme has been tolerated insofar as no bonds are actually purchased. OMT is a policy that does not match stability with growth and, sooner or later, will be found wanting.

(c) Surplus countries will not consent to 'jointly and severally' guaranteed Eurobonds to mutualise debt and deficit countries will resist the loss of sovereignty that would be demanded of them without a properly functioning federal transfer union which Germany, understandably, rejects.

(d) Europe cannot wait for federation. If crisis resolution is made to depend on federation, the Eurozone will fail first. The treaty changes necessary to create a proper European Treasury, with the powers to tax, spend and borrow, cannot, and must not, be held to precede resolution of this crisis.

The next section presents four policies that recognise these constraints.

\section{The Modest Proposal - Four crises, four policies}

The Modest Proposal introduces no new EU institutions and violates no existing treaty. Instead, we propose that existing institutions be used in ways that remain within the letter of European legislation but allow for new functions and policies.

These institutions are:

- The European Central Bank - ECB

- The European Investment Bank - EIB

- The European Investment Fund - EIF

- The European Stability Mechanism - ESM 


\section{Policy 1 - Case-by-Case Bank Programme (CCBP)}

For the time being, we propose that banks in need of recapitalisation from the ESM be turned over to the ESM directly - instead of having the national government borrow on the bank's behalf. Banks from Cyprus, Greece and Spain would likely fall under this proposal. The ESM, and not the national government, would then restructure, recapitalize and resolve the failing banks dedicating the bulk of its funding capacity to this purpose.

The Eurozone must eventually become a single banking area with a single banking authority. But this final goal has become the enemy of good current policy. At the June 2012 European Summit direct bank recapitalisation was agreed upon in principle, but was made conditional on the formation of a Banking Union. Since then, the difficulties of legislating, designing and implementing a Banking Union have meant delay and dithering. A year after that sensible decision, the deadly embrace between insolvent national banking systems and insolvent member-states continues. ${ }^{1}$

Today the dominant EU view remains that banking union must be completed before the ESM directly recapitalises banks. And that when it is complete, the ESM's contribution will be partial and come only after a bail in of depositors in the fiscally stressed countries of the periphery. That way, the banking crisis will either never be resolved or its resolution be delayed for years, risking a new financial implosion.

Our proposal is that a national government should have the option of waiving its right to supervise and resolve a failing bank. Shares equivalent to the needed capital injection will then pass to the ESM, and the ECB and ESM will appoint a new Board of Directors. The new board will conduct a full review of the bank's position and will recommend to the ECB-ESM a course for reform of the bank.

Reform may entail a merger, downsizing, even a full resolution of the bank, with the understanding that steps will be taken to avoid, above all, a haircut of deposits. Once the bank has been restructured and recapitalised, the ESM will sell its shares and recoup its costs.

The above proposal can be implemented today, without a Banking Union or any treaty changes. The experience that the ECB and the ESM will acquire from this case-by-case process will help hone the formation of a proper banking union once the present crisis recedes.

\section{Policy 2 - Limited Debt Conversion Programme (LDCP)}

The Maastricht Treaty permits each European member-state to issue sovereign debt up to $60 \%$ of GDP. Since the crisis of 2008, most Eurozone member-states have exceeded this limit. We propose that the ECB offer member-states the opportunity of a debt conversion for their Maastricht Compliant Debt (MCD), while the national shares of the converted debt would continue to be serviced separately by each member-state.

The ECB, faithful to the non-monetisation constraint (a) above, would not seek to buy or guarantee sovereign MCD debt directly or indirectly. Instead it would act as a go-between, mediating between investors and member-states. In effect, the ECB would orchestrate a conversion servicing loan for the MCD, for the purposes of redeeming those bonds upon maturity. ${ }^{2}$

The conversion servicing loan works as follows. Refinancing of the Maastricht compliant share of the debt, now held in ECB-bonds, would be by member-states but at interest rates set by the ECB just above its bond yields. The shares of national debt converted to ECB-bonds are to be

1 Indeed, recent decisions have made this embrace permanent.

2 For a member state whose debt to GDP ratio is $90 \%$ of GDP, the ratio of its debt that qualifies as MCD is $2 / 3$. Thus, when a bond with face value of say $€ 1$ billion matures, two thirds of this (€667 million) will be paid (redeemed) by the ECB with monies raised (by the ECB itself) from money markets through the issue of ECB bonds 
held by it in debit accounts. These cannot be used as collateral for credit or derivatives creation. ${ }^{3}$ Member states will undertake to redeem bonds in full on maturity, if the holders opt for this rather than to extend them at lower, more secure rates offered by the ECB.

Governments that wish to participate in the scheme can do so on the basis of Enhanced Cooperation, which needs at least nine member-states. ${ }^{4}$ Those not opting in can keep their own bonds even for their MCD. To safeguard the credibility of this conversion, and to provide a backstop for the ECB-bonds that requires no ECB monetisation, member-states agree to afford their ECB debit accounts super-seniority status, and the ECB's conversion servicing loan mechanism may be insured by the ESM, utilising only a small portion of the latter's borrowing capacity. If a member-state goes into a disorderly default before an ECB-bond issued on its behalf matures, then that ECB-bond payment will be covered by insurance purchased or provided by the ESM.

\section{Why not continue with the ECB's OMT?}

The ECB has succeeded in taming interest rate spreads within the Eurozone by means of announcing its Outright Monetary Transactions' programme (OMT). OMT was conceived as unlimited support of stressed Euro-Area bonds -Italy's and Spain's in particular -so as to end the contagion and save the euro from collapse. However, political and institutional pressures meant that the threat against bond dealers, which was implicit in the OMT announcement, had to be diluted to a conditional programme. The conditionality involves troika-supervision over the governments to be helped by the OMT, who are obliged to sign a draconian memorandum of understanding before OMT takes effect. The problem is not only that this of itself does nothing to address the need for both stability and growth, but that the governments of Spain and Italy would not survive signing such a memorandum of understanding, and therefore have not done so.

Thus OMT's success in quelling the bond markets is based on a non-credible threat. So far, not one bond has been purchased. This constitutes an open invitation to bond dealers to test the ECB's resolve at a time of their choosing. It is a temporary fix bound to stop working when circumstances embolden the bond dealers. That may happen when volatility returns to global bond markets once the Federal Reserve and the Bank of Japan begin to curtail their quantitative easing programmes.

\section{Policy 3 - An Investment-led Recovery and Convergence Programme (IRCP)}

In principle the EU already has a recovery and convergence strategy in the European Economic Recovery Programme 2020. In practice this has been shredded by austerity. We propose that the European Union launch a new investment programme to reverse the recession, strengthen European integration, restore private sector confidence and fulfill the commitment of the Rome Treaty to rising standards of living and that of the 1986 Single European Act to economic and social cohesion.

The Investment-led Recovery and Convergence Programme (IRCP) will be co-financed by bonds

3 Any more than a personal debit card can be used for credit.

4 Article 20 (TEU) and Articles 326-334 (TFEU) provide that:

"Enhanced cooperation should aim to further the objectives of the Union, protect its interests and reinforce its integration process. Such cooperation should be open at any time to all Member States. The decision authorising enhanced cooperation should be adopted by the Council as a last resort, when it has established that the objectives of such cooperation cannot be attained within a reasonable period by the Union as a whole, and provided that at least nine Member States participate in it'.

The Council approval of an enhanced cooperation procedure may be unanimous or by qualified majority. But since all member states rather than only those in the Eurozone could gain from investment finance from EIF bond issues, and where its $€$ bonds need not count on national debt, and can attract inflows to the EU from global surpluses, there is a credible prospect of its adoption. 
issued jointly by the European Investment Bank (EIB) ${ }^{5}$ and the European Investment Fund (EIF). The EIB has a remit to invest in health, education, urban renewal, urban environment, green technology and green power generation, while the EIF both can co-finance EIB investment projects and should finance a European Venture Capital Fund, which was part of its original design. ${ }^{6}$

A key principle of this proposal is that investment in these social and environmental domains should be europeanised. Borrowing for such investments should not count on national debt anymore than US Treasury borrowing counts on the debt of California or Delaware. The underrecognised precedents for this are (1) that no major European member state counts EIB borrowing against national debt, and (2) that the EIB has successfully issued bonds since 1958 without national guarantees.

EIB-EIF finance of an IRCP therefore does not need national guarantees or a common fiscal policy. Instead, the joint bonds can be serviced directly by the revenue streams of the EIB-EIFfunded investment projects. This can be carried out within member states and will not need fiscal transfers between them.

A European Venture Capital Fund financed by EIF bonds was backed unanimously by employers and trades unions on the Economic and Social Committee in their 2012 report Restarting Growth. Central European economies (Germany and Austria) already have excellent finance for small and medium firms through their Mittelstandpolitik. It is the peripheral economies that need this, to build new sectors, to foster convergence and cohesion and to address the growing imbalances of competitiveness within the Eurozone.

\section{Rationale}

The transmission mechanism of monetary policy to the periphery of Europe has broken down. Mr Mario Draghi admits this. He has gone on record to suggest that the EIB play a active role in restoring investment financing in the periphery. Mr Draghi is right on this point.

But, for the IRCP to reverse the Eurozone recession and stop the de-coupling of the core from the periphery, it must be large enough to have a significant effect on the GDP of the peripheral countries.

If EIB-EIF bonds are to be issued on this scale, some fear that their yields may rise. But this is far from clear. The world is awash in savings seeking sound investment outlets. Issues of EIF bonds that co-finance EIB investment projects should meet these demands, supporting stability and working to restore growth in the European periphery. We therefore submit that joint EIB-EIF bond issues can succeed without formal guarantees. Nonetheless, in fulfillment of its remit to

5 Since gaining its social investment terms of reference from the European Council in 1997, the European Investment Bank quadrupled its annual lending to over $€ 80$ billions. But, despite the EIB's more than half century of success there also are questions whether it can replicate this again without parallel support. For the EIB is highly dependent on investments in its bonds from pension funds which are statutorily obliged to invest only in AAA rated finance. It also has had a house rule, rather than a Treaty obligation, to seek co-finance for its investments either from national governments or national partners, both of which have been compromised by reactions to the Eurozone crisis since 2009. See below for our recommendation that an expanded investmentled recovery programme should be supported by legitimate ECB operations.

6 Some history: One of the main recommendations by one of us in 1993, in advice to Jacques Delors, was that Europe should establish a European Investment Fund to countervail the deflationary effects of the debt and deficit conditions of the Maastricht Treaty. The proposal was derailed in 1994, both because of vehement resistance from the Economy and Finance Directorate of the Commission and the resistance, then as now, of Germany to EU bonds. [See Stuart Holland (1993). The European Imperative: Economic and Social Cohesion in the 1990s. Foreword Jacques Delors. Nottingham: Spokesman Press, November.] But Delors managed to get the European Investment Fund established. In recent evidence to the Economic and Social Committee of the EU, both the Fund and the EIB confirmed that the EIF could fulfil its original design aim to issue bonds without a Treaty revision. The Economic and Social Committee then endorsed the principle that eurobonds could be adopted by 'enhanced cooperation'. 
support "the general economic policies in the Union", the ECB can issue an advance or precautionary statement that it will partially support EIB-EIF bonds by means of standard central bank refinancing or secondary market operations. Such a statement should suffice to allow the EIB-EIF funded IRCP to be large enough for the purposes of bringing about Europe's recovery.

\section{Misleading arguments and unworkable alternatives:}

- There are calls for bonds to finance infrastructure, neglecting the fact that this has been happening through the European Investment Bank (EIB) for more than half a century. An example is a recent European Commission proposal for 'Project Bonds' to be guaranteed by member states. This assures opposition from many of them, not least Germany, while ignoring the fact that the EIB has issued project bonds successfully since 1958, without such guarantees. ${ }^{7}$

- There is no high-profile awareness that EIB investment finance does not count on the national debt of any major member state of the EU nor need count on that of smaller states. ${ }^{8}$

- There is a widespread presumption that public investment drains the private sector when in fact it sustains and supports it. There is similar presumption that one cannot solve the crisis by 'piling debt on debt'. It depends on which debt for which purpose, and at what rates. Piling up national debt at interest rates of up to seven per cent or more without recovery is suicidal. Funding inflows from global surpluses to Europe to promote economic recovery through joint EIB-EIF bonds at interest rates which could be less than two per cent is entirely sustainable. ${ }^{9}$

- There is little awareness of the EIB's sister organisation, the European Investment Fund (EIF), which has a large potential for investment funding of SMEs, high technology clusters and a variety of other projects, which it can co-finance with bonds, issued jointly with the EIB (see note 6).

\section{Why aren't the EIB-EIF doing this now?}

Until the onset of the Eurozone crisis the EIB had succeeded in gaining national co-finance, or co-finance from national institutions, for its investments. But with the crisis and constraints on co-finance, total annual EIB financing fell from over €82bn in 2008 to only $€ 45 \mathrm{bn}$ last year. The EIF can counterpart and thereby countervail this. It is a sister institution of the EIB within the EIB Group. Like EIB bonds, EIF bonds need not count on national debt nor need national guarantees. The EIB would retain control over project approval and monitoring.

\section{In sum, we recommend that:}

- The IRCP be funded by means of jointly issued EIB and EIF bonds without any formal guarantees or fiscal transfers by member states.

- $\quad$ Both EIB and EIF bonds be redeemed by the revenue stream of the investment projects they fund, as EIB bonds always have been.

\footnotetext{
7 Since the Lisbon European Council in 2000, the EIB has accepted a specific remit for cohesion and convergence. See European Investment Bank (2008). Fifty Years of Sustainable Investment, Luxembourg.

8 None of the major EU economies, nor Greece, Portugal or Ireland count EIB funding as part of national debt. Nor need any others, since whether EIB funding should be counted as part of national debt is a national decision by governments and their central banks rather than embodied in or needing amendments EU Treaties.

9 For two relevant sources see Creel J., P. Monperrus-Veroni \& F. Saraceno (2007). Has the Golden Rule of public finance made a difference in the United Kingdom? OFCE Working Papers 2007-13. Paris: Observatoire Français des Conjonctures Économiques; and Creel, J., Hubert, P. and Saraceno, F. (2012). Should the Stability and Growth Pact be strengthened? OFCE blog. February29th. Paris: Observatoire Français des Conjonctures Économiques.
} 
- If needed, the ECB should stand by to assist in keeping yields low, through direct purchases of EIB-EIF bonds in the secondary market. ${ }^{10}$

\section{Policy 4 - An Emergency Social Solidarity Programme (ESSP)}

We recommend that Europe embark immediately on an Emergency Social Solidarity Programme that will guarantee access to nutrition and to basic energy needs for all Europeans, by means of a European Food Stamp Programme modelled on its US equivalent and a European Minimum Energy Programme.

These programmes would be funded by the European Commission using the interest accumulated within the European system of central banks, from TARGET2 imbalances, profits made from government bond transactions and, in the future, other financial transactions or balance sheet stamp duties that the EU is currently considering.

\section{Rationale}

Europe now faces the worst human and social crisis since the late 1940s. In member-states like Greece, Ireland, Portugal, but also elsewhere in the Eurozone, including core countries, basic needs are not being met. This is true especially for the elderly, the unemployed, for young children, for children in schools, for the disabled, and for the homeless. There is a plain moral imperative to act to satisfy these needs. In addition, Europe faces a clear and present danger from extremism, racism, xenophobia and even outright Nazism - notably in countries like Greece that have borne the brunt of the crisis. Never before have so many Europeans held the European Union and its institutions in such low esteem. The human and social crisis is turning quickly into a question of legitimacy for the European Union.

\section{Reason for TARGET2 funding}

TARGET2 is a technical name for the system of internal accounting of monetary flows between the central banks that make up the European System of Central Banks. In a well balanced Eurozone, where the trade deficit of a member state is financed by a net flow of capital to that same member-state, the liabilities of that state's central bank to the central banks of other states would just equal its assets. Such a balanced flow of trade and capital would yield a TARGET2 figure near zero for all member-states. And that was, more or less, the case throughout the Eurozone before the crisis.

However, the crisis caused major imbalances that were soon reflected in huge TARGET2 imbalances. As inflows of capital to the periphery dried up, and capital began to flow in the opposite direction, the central banks of the peripheral countries began to amass large net liabilities and the central banks of the surplus countries equally large net assets.

The Eurozone's designers had attempted to build a disincentive within the intra-Eurosystem realtime payments' system, so as to prevent the build-up of huge liabilities on one side and corresponding assets on the other. This took the form of charging interest on the net liabilities of each national central bank, at an interest rate equal to the ECB's main refinancing level. These payments are distributed to the central banks of the surplus member-states, which then pass them on to their government treasury.

10 Note that such support would be entirely within the central bank's remit and charter. It would not constitute fiscal financing (as the EIB and EIF are triple-A rated EU institutions) and the precise nature of means by which the ECB can support EIB and EIF bonds may be left to the ECB's governing council to decide. For example, it can take the form of preferential haircut rates at the level of repo refinancing (something already discussed by the ECB's governing board in relation to bundles of loans to the Periphery's SMEs) or, indeed, direct purchases in the secondary markets. 
Thus the Eurozone was built on the assumption that TARGET2 imbalances would be isolated, idiosyncratic events, to be corrected by national policy action. The system did not take account of the possibility that there could be fundamental structural asymmetries and a systemic crisis.

Today, the vast TARGET2 imbalances are the monetary tracks of the crisis. They trace the path of the consequent human and social disaster hitting mainly the deficit regions. The increased TARGET2 interest would never have accrued if the crises had not occurred. They accrue only because, for instance, risk averse Spanish and Greek depositors, reasonably enough, transfer their savings to a Frankfurt bank. As a result, under the rules of the TARGET2 system, the central bank of Spain and of Greece have to pay interest to the Bundesbank - to be passed along to the Federal Government in Berlin. This indirect fiscal boost to the surplus country has no rational or moral basis. Yet the funds are there, and could be used to deflect the social and political danger facing Europe.

There is a strong case to be made that the interest collected from the deficit member-states' central banks should be channelled to an account that would fund our proposed Emergency Social Solidarity Programme (ESSP). Additionally, if the EU introduces a financial transactions' tax, or stamp duty proportional to the size of corporate balance sheets, a similar case can be made as to why these receipts should fund the ESSP. With this proposal, the ESSP is not funded by fiscal transfers nor national taxes.

\section{Conclusion: Four realistic policies to replace of five false choices}

Three years of crisis have culminated in a Europe that has lost legitimacy with its own citizens and credibility with the rest of the world. Europe is unnecessarily back in recession. While the bond markets were placated by the ECB's actions in the summer of 2012, the Eurozone remains on the road toward disintegration.

While this process eats away at Europe's potential for shared prosperity, European governments are imprisoned by false choices:

- between stability and growth

- $\quad$ between austerity and stimulus

- between the deadly embrace of insolvent banks by insolvent governments, and an admirable but undefined and indefinitely delayed Banking Union

- between the principle of perfectly separable country debts and the supposed need to persuade the surplus countries to bankroll the rest

- between national sovereignty and federalism.

These falsely dyadic choices imprison thinking and immobilise governments. They are responsible for a legitimation crisis for the European project. And they risk a catastrophic human, social and democratic crisis in Europe.

By contrast the Modest Proposal counters that:

- The real choice is between beggar-my-neighbour deflation and an investment-led recovery combined with social stabilisation. The investment recovery will be funded by global capital, supplied principally by sovereign wealth funds and by pension funds which are seeking longterm investment outlets. Social stabilisation can be funded, initially, through the Target2 payments scheme.

- Taxpayers in Germany and the other surplus nations do not need to bankroll the 2020 European Economic Recovery Programme, the restructuring of sovereign debt, resolution of the banking crisis, or the emergency humanitarian programme so urgently needed in the European periphery.

- Neither an expansionary monetary policy nor a fiscal stimulus in Germany and other surplus 
countries, though welcome, would be sufficient to bring recovery to Europe.

- Treaty changes for a federal union may be aspired by some, but will take too long, are opposed by many, and are not needed to resolve the crisis now.

On this basis the Modest Proposal's four policies are feasible steps by which to deal decisively with Europe's banking crisis, the debt crisis, underinvestment, unemployment as well as the human, social and political emergency.

This version of the Modest Proposal offers immediate answers to questions about the credibility of the ECB's OMT policy, the impasse on a Banking Union, financing of SMEs through EIF bonds enabling a European Venture Capital Fund, green energy and high tech start-ups in Europe's periphery, and basic human needs that the crisis has left untended.

It is not known how many strokes Alexander the Great needed to cut the Gordian knot. But in four strokes, Europe could cut through the knot of debt and deficits in which it has bound itself.

- In one stroke, Policy 1, the Case-by-Case Bank Programme (CCBP), bypasses the impasse of Banking Union (BU), decoupling stressed sovereign debt and from banking recapitalisation, and allowing for a proper BU to be designed at leisure

- By another stroke, Policy 2, the Limited Debt Conversion Programme (LDCP), the Eurozone's mountain of debt shrinks, through an ECB-ESM conversion of Maastricht Compliant member-state Debt

- By a third stroke, Policy 3, the Investment-led Recovery and Convergence Programme (IRCP) re-cycles global surpluses into European investments

- $\quad$ By a fourth stroke, Policy 4, the Emergency Social Solidarity Programme (ESSP), deploys funds created from the asymmetries that helped cause the crisis to meet basic human needs caused by the crisis itself.

At the political level, the four policies of the Modest Proposal constitute a process of decentralised europeanisation, to be juxtaposed against an authoritarian federation that has not been put to European electorates, is unlikely to be endorsed by them, and, critically, offers them no assurance of higher levels of employment and welfare.

We propose that four areas of economic activity be europeanised: banks in need of ESM capital injections, sovereign debt management, the recycling of European and global savings into socially productive investment and prompt financing of a basic social emergency programme.

Our proposed europeanisation of borrowing for investment retains a large degree of subsidiarity. It is consistent with greater sovereignty for member-states than that implied by a federal structure, and it is compatible with the principle of reducing excess national debt, once banks, debt and investment flows are europeanised without the need for national guarantees or fiscal transfers.

While broad in scope, the Modest Proposal suggests no new institutions and does not aim at redesigning the Eurozone. It needs no new rules, fiscal compacts, or troikas. It requires no prior agreement to move in a federal direction while allowing for consent through enhanced cooperation rather than imposition of austerity.

It is in this sense that this proposal is, indeed, modest. 